\title{
Bacteriological and chemical properties of soil amended with fermented poultry bird feather
}

\author{
A.D. IBRAHIM ${ }^{1 *}$, A.B. RABAH ${ }^{1}$, M.L. IBRAHIM ${ }^{1}$, I.M. MAGAMI ${ }^{2}$, J.G. ISAH ${ }^{1}$ and \\ O. I. $\mathrm{MUZOH}^{3}$ \\ ${ }^{1}$ Department of Microbiology, Usmanu Danfodiyo University, Sokoto, Nigeria. \\ ${ }^{2}$ Department of Biological Sciences, Usmanu Danfodiyo University, Sokoto, Nigeria. \\ ${ }^{3}$ Department of Soil Science, University of Nigeria, Nsukka, Nigeria. \\ *Corresponding author; E-mail: ibrahim.aliyu@udusok.edu.ng ; aid4life@yahoo.com
}

\begin{abstract}
Huge amount of poultry wastes are generated annually in developing nations, of which end up in our environment. Feather as a poultry waste have caused environmental concerns in many of these countries. In this research work, poultry feather was used to study its effects on bacteriological and chemical properties in agricultural soil. The feathers collected were grinded, sterilized and fermented before mixing it with soil. Total heterotrophic counts of colonies were enumerated from the soil samples. Isolates were characterized based on morphological and series of biochemical tests. Soil chemical analysis for $\mathrm{pH}$, carbon, nitrogen, phosphorus, calcium, potassium was also carried out. The heterotrophic bacteria count of the treated soil had the highest count in the range of $1.54 \times 10^{6}$ to $2.02 \times 10^{6}(\mathrm{CFU} / \mathrm{g})$ as against the control soil with $1.24 \times 10^{6}(\mathrm{CFU} / \mathrm{g})$. The bacteria identified from these samples were Bacillus sp., Proteus sp., Staphylococcus sp. and Actinomyces sp. Actinomyces sp. was isolated only after three weeks of treatment with the feather while all other bacteria were also present in the control soil but at elevated levels based on heterotrophic bacteria count in the treated soil. The soil chemical analysis of the treated soil had high amount of mineral (Organic carbon $1.10 \%$, nitrogen $0.09 \%$, phosphorus $0.53 \pm 0.02 \mathrm{mg} / \mathrm{kg}$, magnesium $0.45 \pm 0.01 \mathrm{mg} / \mathrm{kg}$ as against the control (Organic carbon $0.26 \%$, nitrogen $0.05 \%$, phosphorus $0.30 \pm 0.10 \mathrm{mg} / \mathrm{kg}$, magnesium $0.45 \pm 0.01 \mathrm{mg} / \mathrm{kg}$ ) and their $\mathrm{pH}$ is almost near neutrality, 7.12 and 7.08 respectively. The result suggested that soil treated with poultry feather increased the plate count of Bacillus sp, Proteus sp, Staphylococcus sp and Actinomyces sp. Poultry feather which is a waste by-product can provide essential nutrients for the survival of soil microorganisms, plant growth and therefore can be exploited as biofertilizer.
\end{abstract}

(C) 2014 International Formulae Group. All rights reserved.

Keywords: Bacillus sp., biofertilizer, fermentation, keratin, poultry waste.

\section{INTRODUCTION}

Poultry industry has witnessed huge rise in production over the years and the increase has also caused the generation of an enormous amount of poultry by-product. The by-product generated from the activities of the industry includes residues such as feather, bone meal, blood and offal. Chicken feathers make up about $5 \%$ of the body weight of chicken and form a considerable amount of waste product from the poultry industry. The amount of feather generated by the poultry industry has 
been estimated at about 4 million tons per year globally (Friedrich et al., 2005). The disposal of waste feathers is a major concern for the poultry industry. The feather eventually finds their way to the environment where they accumulate in the large amount thereby resulting in environmental pollution and protein wastage (Onifade et al., 1998). To date, only minor quantity of waste feathers is exploited industrially for clothing, insulation and bedding, producing biodegradable polymers, microbial enzymes and microbial culture medium (Manczinger et al., 2003).

Feathers are also a good source of soil organic matter which plays a key role in maintaining soil fertility and productivity. The effect of the organic matter may be either direct or indirect. Organic matter acts as a direct source of plant nutrients and in an indirect manner influences the physical and biological properties of the soil (Chesworth, 2008). Among the means available to achieve sustainability in agricultural production, organic manure and biofertilizer play an important and key role on the desired soil properties and exerts a beneficial effect on all soil characteristics (Soleimanzadeh and Ghooshchi, 2013). In this regard, an attempt has been made to study the influence of fermented feather as biofertilizer on garden soil. This research was conducted to determine the effects of poultry feather on soil bacteria and chemical composition.

\section{MATERIALS AND METHODS}

\section{Sample collection}

Three bags of poultry feather were collected from Sokoto meat and vegetable market in Sokoto metropolis and transported to Microbiology laboratory of Usmanu Danfodiyo University Sokoto, Nigeria.

\section{Sample processing}

The feather collected were dried using bakery oven, and grinded by grinding machine and further grounded to a powdery form using mortar and pestle. The powder was sieved several times to obtain a fine powder and remove the large particles.

\section{Inoculum preparation}

The pure culture of Bacillus spp isolated from feather dumpsite in Sokoto metropolis was used in preparing the inoculum using 0.5 McFarland turbidity standards. The inoculum prepared corresponded to third test tube of McFarland scale. This means 900 cells were used as inoculum for the fermentation.

\section{Fermentation}

The fermentation was done in $20 \mathrm{~mL}$ jar. The sterilized grinded feather slurry (feather: water in 1:3) was transferred into the $20 \mathrm{~mL}$ jar and it was seeded with the Bacillus sp. and allowed to ferment at room temperature. The jar was stirred after every 4 hours in order to ensure aeration and uniformity in the fermentation. After a period of 3 days, fermentation was assumed to be completed from its bacterial fermentation. The fermented feather is then taken immediately to the school garden for further study.

\section{Treatment of garden soil with the fermented feather}

The fermented feathers were taken to the biological sciences garden where it was mixed with soil of a plot of 15 by 5 feet's. This mixture of the soil garden and feather were taken to the Microbiology and Soil Science Laboratories for further investigations.

\section{Bacteriological analysis}

This was done according to the standard protocol for the isolation of bacteria (Singleton, 1997). Serial dilution was conducted and $100 \mu \mathrm{L}$ was inoculated into sterilized nutrient agar culture medium and incubated for overnight at temperature of 37 ${ }^{\mathrm{O}} \mathrm{C}$. The growth of different colonies were observed, counted and subculture to obtain pure colonies. The pure culture was then gram stained and used for various biochemical analysis. The results of the biochemical 
analysis were then used to identify the bacterial isolates (MacFaddin, 2000).

\section{Mineral analysis}

Analysis of minerals was done according to methods described elsewhere (Hack, 2000). The investigated minerals include phosphorus, sodium, calcium and magnesium. Phosphorus was determined using spectrophotometer (JENWAY 6100) at $660 \gamma$ (wavelength), potassium and sodium were determined using flame photometer (Corning 400 Essex, England), while that of magnesium and calcium was done using ethylene diamine tetra acetic acid (EDTA) titration method. The organic carbon in soil was determined by quantitative drycombustion procedures (AOAC, 1995). The soil samples were oxidized in a current of purified oxygen gas and the evolved $\mathrm{CO}_{2}$ was collected in ascarite (Asbestos $+\mathrm{NaOH}$ ). The tube containing ascarite is weighed before and after passing $\mathrm{CO}_{2}$ and the amount of organic carbon were determined by differences as: Total C - inorganic $\mathrm{C}=$ organic carbon (AOAC, 1995).

\section{RESULTS}

The analysis of the heterotrophic bacteria count of soil amended with fermented feather was conducted and the result showed increased bacteria count in the amended soils (Figure 1). The heterotrophic count of the bacteria isolated from the amended soil was in the range of $1.54 \times 10^{6}$ to $2.02 \times 10^{6}(\mathrm{CFU} / \mathrm{g})$ as against that of control soil with $1.24 \times 10^{6}$ (CFU/g).

Analysis of the viable bacteria population shows that the amended and control soil are Bacillus sp., Proteus sp., Staphylococcus sp. and Actinomyces sp. (Table 1). Actinomyces sp was identified after 3 weeks of amendment with the fermented feather and the other group of bacteria appears to be stable members of the soil microbial community. Bacillus sp are the dominant group of organisms with $58.8 \%$ while Proteus sp. and Actinomyces sp. were the least encountered bacteria group with $5.9 \%$ occurrences each (Table 2).

Analysis of the soil chemical profile shows that amended soil had the highest values for soil $\mathrm{pH}(7.12 \pm 0.02)$, organic carbon $(1.10 \pm 0.10 \%)$, nitrogen $(0.09 \pm 0.01 \%)$, phosphorus $\quad(0.53 \pm 0.02 \quad \mathrm{mg} / \mathrm{kg}) \quad$ and magnesium with $0.45 \pm 0.01 \mathrm{mg} / \mathrm{kg}$ (Table 3 ). These values decreased along the time course of the experiment with nitrogen returning to the same value as the control $(0.05 \pm 0.20 \%)$ after three weeks.

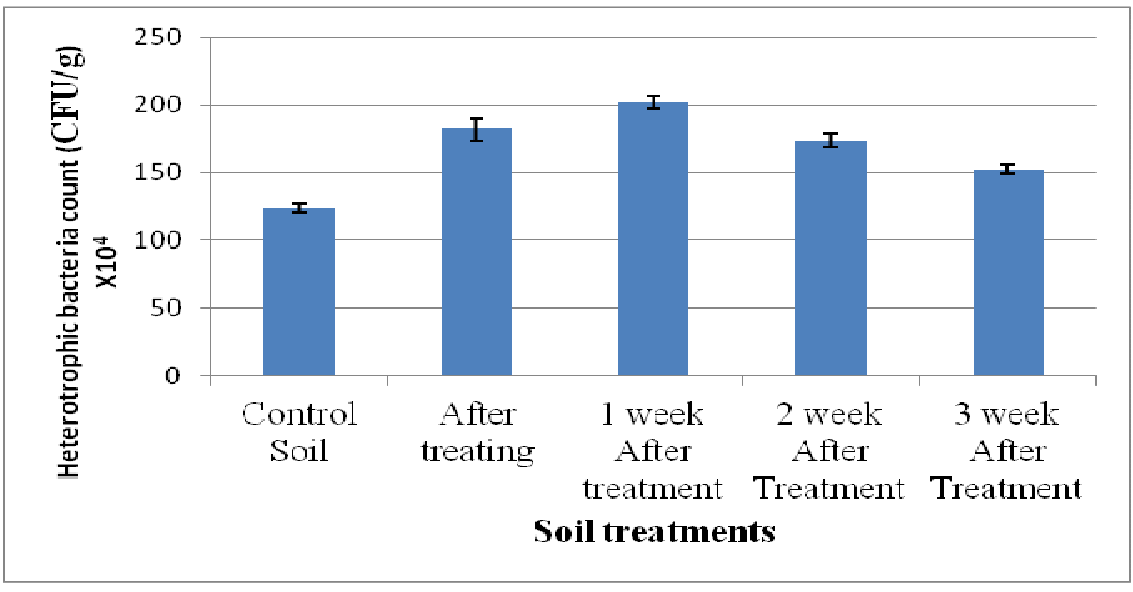

Figure 1: Heterotrophic bacterial counts of soil treated with fermented feather. 
Table 1: Bacteria identified from each soil samples following amendment with fermented poultry feather over 3 week period.

\begin{tabular}{ll}
\hline Samples & Organisms isolated \\
\hline Control soil & Staphylococcus chromogenes, Proteus sp., Bacillus sp \\
After treatment & Bacillus brevis, Bacillus licheniformis, Bacillus subtilis, \\
& Staphylococcus chromogenes \\
& Bacillus subtilis, Bacillus licheniformis, Staphylococcus \\
treatment & chromogenes, \\
2 weeks after treatment & Bacillus licheniformis, Bacillus brevis Staphylococcus epidermidis \\
3 weeks after treatment & Actinomyces sp, Bacillus subtilis, Bacillus licheniformis, \\
& Staphylococcus capitis \\
\hline
\end{tabular}

Table 2: Frequency of occurrence of bacterial isolates over the period of treatment.

\begin{tabular}{lcc}
\hline Isolates & Occurrence(n) & Percentage of occurrence (\%) \\
\hline Bacillus sp. & 10 & 58.8 \\
Staphylococcus sp. & 5 & 29.4 \\
Actinomyces sp. & 1 & 5.9 \\
Proteus sp. & 1 & 5.9 \\
Total & $\mathbf{1 7}$ & $\mathbf{1 0 0}$ \\
\hline
\end{tabular}

Table 3: Proximate analysis of the soil samples amended with fermented feather.

\begin{tabular}{lccccc}
\hline Parameter & \multicolumn{5}{c}{ Samples } \\
\cline { 2 - 6 } & Control soil & $\begin{array}{c}\text { After } \\
\text { treatment }\end{array}$ & $\begin{array}{c}\text { 1 week after } \\
\text { treatment }\end{array}$ & $\begin{array}{c}\text { 2 weeks after } \\
\text { treatment }\end{array}$ & $\begin{array}{c}\text { 3 weeks after } \\
\text { treatment }\end{array}$ \\
\hline $\mathrm{pH}$ & $7.08 \pm 0.02$ & $7.12 \pm 0.02$ & $6.89 \pm 0.01$ & $6.75 \pm 0.10$ & $6.66 \pm 0.11$ \\
Organic Carbon $(\%)$ & $0.26 \pm 0.02$ & $1.10 \pm 0.10$ & $0.72 \pm 0.01$ & $0.44 \pm 0.30$ & $0.41 \pm 0.21$ \\
Nitrogen $(\%)$ & $0.05 \pm 0.10$ & $0.09 \pm 0.01$ & $0.06 \pm 0.001$ & $0.06 \pm 0.10$ & $0.05 \pm 0.20$ \\
Phosphorus $(\mathrm{mg} / \mathrm{kg})$ & $0.30 \pm 0.10$ & $0.53 \pm 0.02$ & $0.41 \pm 0.015$ & $0.41 \pm 0.20$ & $0.40 \pm 0.10$ \\
Sodium $(\mathrm{mg} / \mathrm{kg})$ & $0.43 \pm 0.01$ & $0.70 \pm 0.01$ & $0.78 \pm 0.01$ & $0.65 \pm 0.50$ & $0.60 \pm 0.15$ \\
Calcium $(\mathrm{mg} / \mathrm{kg})$ & $0.35 \pm 0.03$ & $0.60 \pm 0.03$ & $0.60 \pm 0.10$ & $0.55 \pm 0.10$ & $0.50 \pm 0.10$ \\
Magnesium $(\mathrm{mg} / \mathrm{kg})$ & $0.45 \pm 0.01$ & $0.45 \pm 0.01$ & $0.35 \pm 0.10$ & $0.40 \pm 0.15$ & $0.39 \pm 0.40$ \\
Cation exchange & $7.72 \pm 0.02$ & $8.74 \pm 0.01$ & $9.14 \pm 0.10$ & $8.24 \pm 0.10$ & $8.12 \pm 0.10$ \\
capacity $(\mathrm{Cmol} / \mathrm{kg})$ & & & & & \\
\hline
\end{tabular}

Each data point presented as Mean \pm Standard Deviation $(n=3)$; Means along the same column with different superscript are significantly different at $\mathrm{P}<0.05$.

\section{DISCUSSION}

The presence of poultry feather on soil increases the bacterial count of the soil. The control soil has a total of bacterial colony count of $1.24 \times 10^{6}(\mathrm{cfu} / \mathrm{g})$ which is low compared to the soil treated with the feather which ranges from $1.52 \times 10^{6}$ to $2.02 \times 10^{6}$ (cfu/g) (Figure 1). This may be as a result of the bacterial isolate used in fermenting the feather. There is also possibility of the availability of essential nutrient in feather to stimulate the growth and multiplication of the organisms. However, the sample collected after 1 week of treatments with feather shows 
the highest range of bacterial count $\left(2.02 \times 10^{6} \mathrm{cfu} / \mathrm{g}\right)$ compared to the one collected immediately after treating (1.83 $\left.\mathrm{x} 10^{6} \mathrm{cfu} / \mathrm{g}\right)$ and those collected after 2 weeks $\left(1.74 \times 10^{6} \mathrm{cfu} / \mathrm{g}\right)$ and 3 weeks $(1.52$ $\left.\mathrm{x} 10^{6} \mathrm{cfu} / \mathrm{g}\right)$ respectively. This means that 1 week after treatment, the organisms present in the soil have adapted to the changes as a result of the feather amendment and they are capable of producing enzymes that aid them in utilizing the feather for their growth and multiplication (Cheng et al., 1995). Likewise, the bacterial colonies count of the sample collected immediately after mixing the soil with feather is not much in the sense that the organisms present were in log phase trying to adapt to the environmental changes and produces the enzymes that will degrade the feather and utilize it as a source of carbon and energy. This confirms with report of feather degradation by (Cai and Zheng, 2009) who has reported increase in microbial population in soil contaminated with the feather after some days. However, in 2-3 weeks times, there will be reduction of carbon source. Therefore, competition and accumulation of metabolic by-products sets in leading to decrease in bacterial population.

The bacteria identified from these amended and control soil is mostly Bacillus sp. Including Bacillus licheniformis, Bacillus brevis and Bacillus subtilis, having $58.8 \%$ of occurrence. Staphylococcus sp include $S$. chromogenes and S. epidermidis, has $29.4 \%$ while Actinomyces sp and Proteus mirabilis had $5.9 \%$ each. These organisms have been reported elsewhere as degraders of feather (Kim et al., 2001; Jayalakshmi et al., 2011; Lakshmi et al., 2013; VenkataNagaRaju and Divakar, 2013). Staphylococcus chromogenes occurs in both samples that were treated with feather and in control soil. This may be due to lesser effects of feather on soil $\mathrm{pH}$ and it ability to utilize feather as source of carbon and energy. The result revealed that poultry feather has minor effect on soil $\mathrm{pH}$; therefore, it has less effect on soil microbial community. These bacteria that were identified are beneficial to soil due to their ability of producing keratinase (Jayalakshmi et al., 2011; Kim et al., 2001) and cellulases enzymes that aids in breaking down of dead organic matters thereby making nutrients available to plants. Apart from this, they are the constituents of rhizophere in root nodules of legume plants for fixation of Nitrogen.

The soil sample treated with feather showed a wide variation in physicochemical composition as compared to that of control. The highest result of organic carbon, Nitrogen, phosphorus, calcium were obtained from the sample collected immediately after mixing the soil with the feather. This may be due to fact that these minerals have not been used by soil microbes as against the results of the sample collected after some weeks of treatment with fermented feather. This finding agrees with the work of Tan et al. (2008) in biodegradation of feather and reveals that the initial outcome is higher compared to subsequent ones.

\section{Conclusion}

Fermented poultry feathers are used to amend soil result in an increased in heterotrophic bacteria count from $1.54 \times 10^{6}$ to $2.02 \times 10^{6}(\mathrm{CFU} / \mathrm{g})$ as against the control soil with $1.24 \times 10^{6} \quad(\mathrm{CFU} / \mathrm{g})$. The bacteria identified from these samples were Bacillus $s p$, Proteus sp, Staphylococcus sp and Actinomyces sp. Actinomyces sp. There was also an increase in organic carbon and all mineral elements evaluated and the organic carbon and mineral elements decreased over the time course of the research work. The result obtained from this study indicates that fermented poultry feather can be used to amend soil as it intensified microbial activity in soil thereby improving soil due to its mineral composition that are essential for both plant and microbial growth. It does not only supply nutrient to plants and promotes microbial activity, but also improves soil structures and increase water retention capacity. 


\section{REFERENCES}

AOAC 1995. Official Method of Analysis. Association of Official Analytical Chemists: Washington, DC.; U.S.A.

Cai C, Zheng X. 2009. Medium optimization for keratinase production in hair substrate by a new Bacillus subtilis KD-N2 using response surface methodology. J. Ind. Microb. Biotechnol., 36: 875- 883.

Chesworth W. 2008. Encyclopedia of Soil Sciences. Springer Dordrecht: The Nehterlands; 614.

Cheng SW, Hu HM, Shen SW, Takagi H, Asano M, Tsai YC. 1995. Production and characterization of keratinase of a featherdegrading Bacillus licheniformis PWD-1. Biosci. Biotechnol. Biochem., 59: 22392243.

Friedrich J, Gradisar H, Vrecl M, Pogacnik A. 2005. In vitro degradation of porcine skin epidermis by a fungal keratinase of Doratomyce Microsporus. Enzyme Microbial Technol., 36(4): 455460.

Hack B. 2000. Analytical method of determination of mineral nutrients. In Text on Analytical in Practice, Dolphin, John S (eds). Incorp Press: New York; 26-33.

Jayalakshmi T, Krishnamoorthy P, Kumar GR; Sivamani P. 2011. Biochemical Characterization of Microbial keratinases from Actinomycetes for Chick Feather Wastes. Journal of Pharmacy Research, 4(9): 3150.

Kim JM, Lim WJ, Suh HJ. 2001. Featherdegrading Bacillus species from poultry waste. Process Biochemistry, 37(3): 287291.

Lakshmi TBV, Chowdary YA, Soumya M, GayatriDevi p, Anuradha K, Madhuri A. 2013. Degradation of chicken feathers by Proteus vulgaris and Micrococcus leteus.
Intl. J. Pharm. Biol. Archives. 4(2): 366370.

MacFaddin JF. 2000. Biochemical Tests for Identification of Medical Bacteria. Lippincott, Williams \$Wilkins: Baltimore, 912.

Manczinger L, Rozs M, Vagvolgyi C, Kevei F. 2003. Isolation and characterization of a new keratinolytic Bacillus licheniformis strain. World J Microbiol Biotechnol., 19(1): 35-39.

Onifade AA, A1-Sane NA, AI-Musallam AA, Al-Zarban S. 1998. Potentials for biotechnological applications of keratindegrading microorganisms and their enzymes for nutritional improvement of feathers and other keratins as livestock feed resources. Bioresour. Technol., 66:111.

Singleton P. 1997. The identification and classification of Bacteria In Biology, Biotechnology and Medicine. $\left(4^{\text {th }}\right.$ edn). John Wiley and sons: England; 340 348.

Soleimanzadeh H, Ghooshchi F. 2013. Response to growth and yield of maize to biofertilezer in organic and conventional cropping systems. Intl. J. Agric. Crop Sci., 5(7): 797-801.

Tan TW, Zhang M, Wang BW, Ying CH, Deng L. 2003. Screening of high lipase producing Candida sp. and production of lipase by fermentation. Process Biochem., 39(4): 459-465.

Venkata Naga Raju E, Divakar G. 2013. Screening and isolation of keratinase producing bacteria from poultry waste. Intl. J. Pharm. Res. Allied Sci., 2(1): 7074. 